\title{
Integrated sequence-, bio- and chemo- stratigraphy of the terminal Proterozoic to Lowermost Cambrian "black rock series" from central South China
}

\author{
1. Yichang Institute of Geology and Mineral Resources, 21 Gangyao Road, Yichang 443003, China
}

2. Institute of Geology and Palaeontology, Techincal University of Berlin (TUB), Germany

Integrated litho-, bio-, and chemostratigraphic study from the stratigraphic interval of the Nantuo postglacial to Lowermost Cambrian in the central South China suggests that five sequences of third grade could be recognized in the central Yangtze platform (CYP) and its Jiangnan marginal slope (JMS) or basin (JMB) and Xiang-Qian back-arc basin (XQBB). Each sequence turnover is always related to the occurrence of "black rock series" (cherts, shales, dolomites and limestones) accompanied by an oxidizing TST following a shallowing upward HST of the last sequence. These "black rock series" are thought to be formed in a relatively lowenergy but current-influenced subtidal environment, regardless of their difference in paleogeographic locations, and characterized by high original organic matter contents, probably derived from primary rather highly diversified megaalgae, vendobiota, soft-bodied metabiota and prokaryotic bacteria during the Neoproterozoic III, and later from multiphyletic small shelly fossils and planktonic trilobites during the lowest Cambrian. The differentiation of organic matter contents for different black rock types of the same horizon is related to paleo-weathering activities and to the hydrothermal activities in association with the impregnation of high sulfide-related rare and precious metal elements caused by subsequent tectono-thermal events. For the most cherts of the Upper Sinian Liuchapo Formation or coeval beds the silicification is interpreted to have resulted from prediagenetic hydrothermal replacement of primary black muds. The apparent "anoxia" expressed by these "black rock series" does not mean the absence of oxygen in the original oceanic environment during that time or in the shallow water column, but rather virtually the depletion of oxygen occurs at the sediment/water interface due to sedimentary organic surplus stockpiling and disruption as well as disintegration of organic matter during burial and also during early phases of diagenesis. The occurrence of four main biotic assemblages i.e. the Miaohe biota, Vendotaenia with Ediacara-type soft-bodied metazoans, multiphyletic small shelly fossils and trilobites in the terminal Precambrian to earliest Cambrian "black rock series" is related to shallow-water originally oxidizing transgressive environments in the CYP and JMB. The main reason for the usual absence of most of these organicwalled non-skeletal biota in the "black rock series" of same age in the XQBB would probably have been influenced by volcanically derived hydrothermal activities leading to a rising seafloor water temperature during that time, and coincidentally to a relative deep "anoxia" environment as well. Two obvious changes in the distribution of REE, EBP and Sa/Ar are observed between sequence 3 and 4 and between sequence 4 and 5 in $X Q B B$. These two sequence boundaries would separately be equivalent to those between the Precambrian and Cambrian and between the Yanjiahe and Shujingtuo Formations in the Yangtze Platform.

\section{Introduction}

The terminal Proterozoic (Neoproterozoic III or Sinian) and Lowermost Cambrian "black rock series" (or so-called black cherts and shales) are widespread on the eastern Yangtze paraplatform to basin transitional region of southern China. This principally anoxic facies predominates in Members 2 and 4 of the Upper Sinian Doushantuo Formation and in the Liuchapo Formation (basin facies) or in the Shibantan and equivalent members of the Dengying Formation (platform margin facies) as well as in the basal Cambrian Xiaoyanxi Formation (basin) or Shuijingtuo Formation (platform). These "black rock series" are not only significant "host rock" of a significant proportion of organic matter and a pronounced signal of biological and biochemical primary productivity including some soft-bodied metabiota, megaalgae and very initial skeletal metazoan fauna but also contain significant amounts of sulfide-related rare and precious metal elements and mineral deposites.

Integrated study of sequence-, bio- and chemo-stratigraphic signals preserved in these "black rock series" will deepen an understanding of geological and biological events occurring in this 'turnover' epoch of Earth history and will provide new data for revealing the paleo-oceanic environment and genetic factors of these 


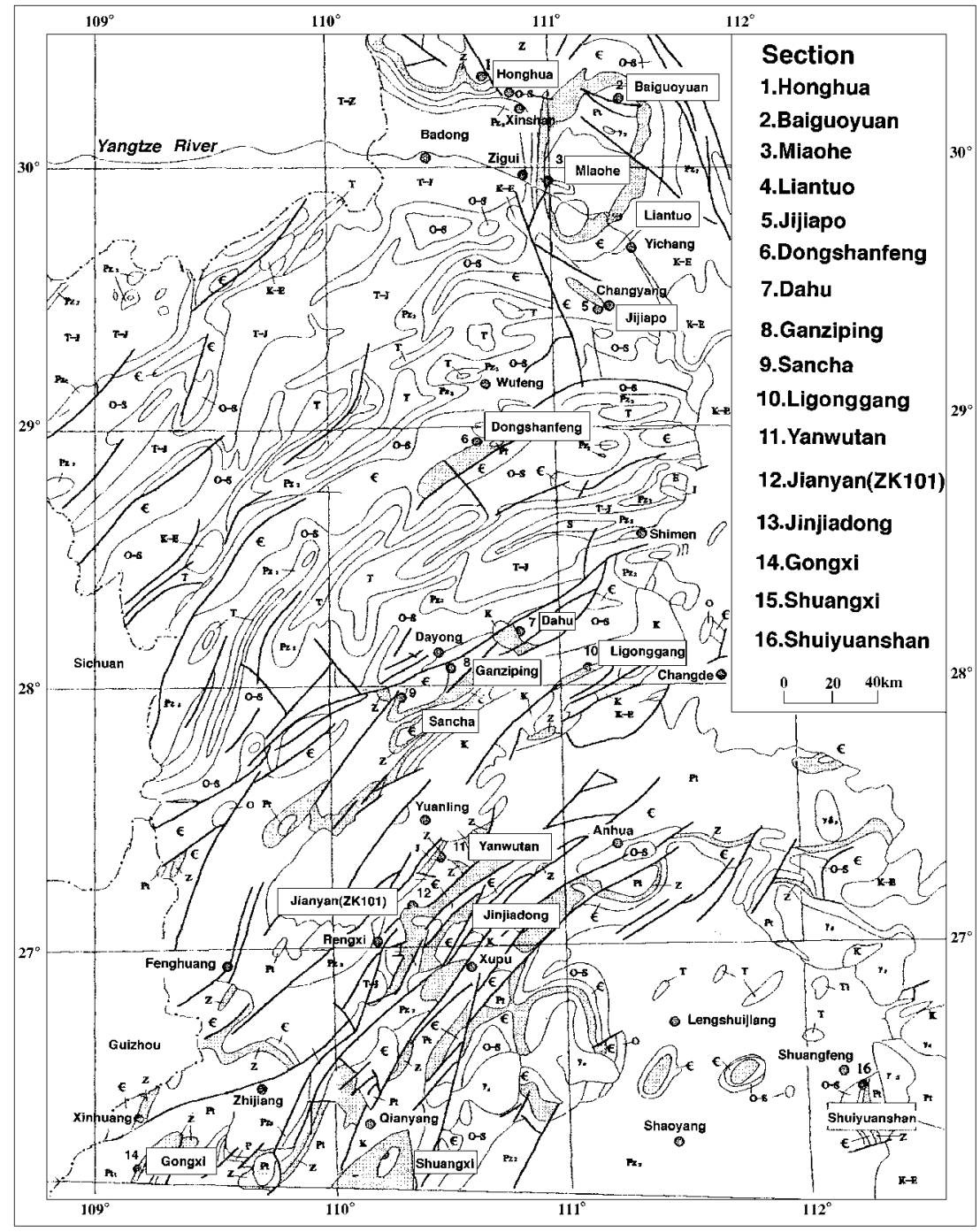

Figure 1 Map showing localities of field investigation.

"black rock series" as well as their relation with accompanying rare and precious metal elements. Hence, such a 'hot' but vital problem in our geological research becomes the starting point and main aim of this particular cooperative project that was initiated between TUB, Germany and the Yichang Institute of Geology and Mineral Resources (YIGMR) associated with the China University of Geosciences at Beijing and being financially supported by both DFG and the Chinese Academy of Geological Sciences (CAGS).

This paper intends to summarize a part of the research results of this project between late 1995 to early 1997 on the basis of analyses of sedimentary facies, chemo-, bio- and sequence-stratigraphy of the terminal Proterozoic to lowermost Cambrian "black rock series" from sections going through the central Yangtze platform to basin transitional region (Figure 1). The regions jointly investigated by the Sino-German team include W. Hubei, N.W. Hunan and the border of Hunan with Guizhou in south-central China.

\section{Geological Setting}

Sinian or terminal Proterozoic rocks are considered the first sedimentary covering strata formed after consolidation of the South China paleocontinental nucleus during the end of the Jinning orogenic phase. The paleogeographic differentiation is manifested mainly by the development of continental and platform marginal uplifts and depressions of back-arc basins. In the studied region the following three main tectono-paleogeographic units may be recognized during Early Sinian (Figure 2).

1. Central Yangtze nearshore platform facies, which is distributed around the Upper Yangtze Oldland.

2. Jiangnan shelf-marginal facies, which is distributed in SW Hubei and NW Hunan and separated from the nearshore area by distinctive facies differentiation between them.

3. Xiang (Hunan)-Qian (Guizhou) back-arc basin, which is distributed in Central Hunan, E. Guizhou and N. Guangxi and separated from the Jiangnan shelf-marginal area and from the South China basin by the Xuefeng island arc in the north and the Hengshan-Jiuling island arc in the south.

During the late Early Sinian the studied region was again uplifted in association with the regression caused by multiple prograding glaciations. Accompanying the postglacial deglaciation the South China landmass underwent widespread transgression, leaving only small islands above water which were scattered over the platform and along the continent margins. During the Late Sinian the central Yangtze nearshore facies of the Early Sinian was transferred to the shallow inner shelf or epicontinental platform, and the Jiangnan shelf evolved into a platform marginal slope or off-shelf facies. The Xiang-Qian backarc basin further developed to a starved inter-arc basin, which was separated from the southeastern China oceanic basin by a series of island arcs. This tectono-paleogeographic differentiation persisted till the earliest Cambrian, even though altogether five main transgressive-regressive cycles had occurred during this interval of ca. 1.55 million years between the global "icehouse" event and the beginning of the Cambrian.

\section{Litho- and sequence- stratigraphic subdivisions}

The Sinian System including the lowermost Cambrian in the type area of the eastern Yangtze Gorges is subdivided, in ascending order, into the Lower Sinian Liantuo, Gucheng, Datangpo, Nantuo Formations and the Upper Sinian Doushantuo and Dengying Formations (the latter including the Hamajing, Shibantan, Baimatuo Members and lithologically also the actually lowest Cambrian Tianzhushan Member) and the Lower Cambrian Shuijingtuo Formation. The total

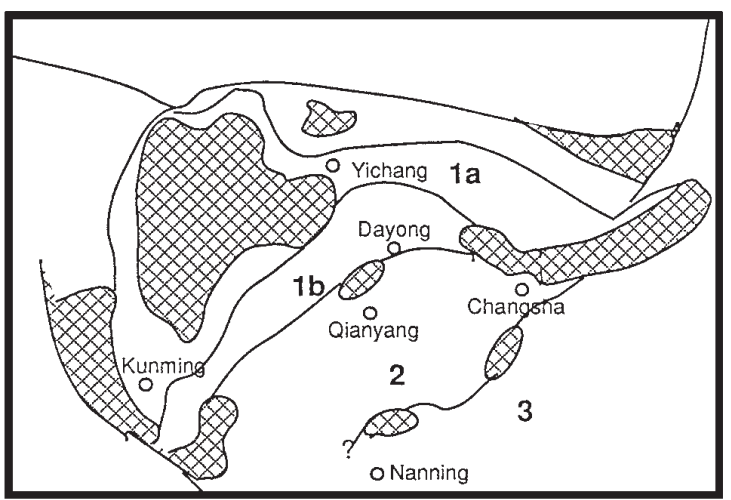

Figure 2 Simplified tectono-paleogeographic map of the Sinian to Earliest Cambrian of south central China. 1a. Central Yangtze inner shelf, 1b. Jiangnan platform marginal slope or off-shelf, 2. Xiang-Qian basinal marginal slope or interarc basin, 3. S. E. China continental margin. Shaded areas: emergent 'oldlands'. 
thickness is ca. 1,100 $\mathrm{m}$ in the type area of the Xiling Gorge, west of Yichang. This stratigraphic interval has conventionally been correlated on the basis of two features: glacigenic sediments and the remains of soft body metabiotas, megaalgae and skeletal fauna mainly preserved in the "black rock series". For the investigations of this cooperative project we concentrate our efforts on the Upper Sinian to lowermost Cambrian interval, especially those beds of the "black rock series" which are developed within this interval. After the Nantuo glacigenic event, the Upper Sinian to Lower Cambrian consists of a set of carbonates intercalated with carbonaceous and siliceous rocks in the central Yangtze shallow epicontinental platform and also along the Jiangnan platform marginal slope, and of black cherts carbonaceous siliceous shales intercalated with carbonates in the Xiang-Qian back-arc basin, respectively. Based on the 16 sections investigated for this study, the lithostratigraphic units cutting through three tectono-paleogeographic facies can be recognized as shown below (Table 1).

Table 1 The Upper Sinian-Lowermost Cambrian lithostratigraphic succession from W. Hubei to central Hunan.

\begin{tabular}{|c|c|c|c|c|c|c|}
\hline Age & \multicolumn{2}{|c|}{$\begin{array}{l}\text { Yangtze epicont.platform } \\
\text { (W.Hubei-W.Hunan) }\end{array}$} & \multicolumn{2}{|c|}{$\begin{array}{l}\text { Jiangnan platform marginal } \\
\text { slope (SW Hubei-NW Hunan) }\end{array}$} & \multicolumn{2}{|c|}{$\begin{array}{l}\text { Xiang-Qian back-arc ba } \\
\text { sin C.Hunan-E.Guizhou }\end{array}$} \\
\hline \multirow{4}{*}{ L.Cam. } & \multirow{4}{*}{ 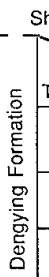 } & \multirow{3}{*}{$\begin{array}{l}\text { Yanijintuo Fm. } \\
\text { Tianzhushan Mb. } \\
\text { Baimatuo Mb. }\end{array}$} & \multirow{4}{*}{$\begin{array}{l}\text { Niutitang } \mathrm{Fm} \text {. } \\
----\end{array}$} & \multirow{3}{*}{$\begin{array}{l}\text { Upper Mb. } \\
\text { Lower Mb } \\
-\quad--- \\
\text { U. Mb. }\end{array}$} & \multicolumn{2}{|c|}{ _ Xiaoyanxi Fm. } \\
\hline & & & & & \multirow{3}{*}{$\begin{array}{l}\text { Liuchapo } \\
\text { Formation }\end{array}$} & \\
\hline & & & & & & $U$. chert \\
\hline & & $\begin{array}{l}\text { Shibantan Mb. } \\
\text { Hamajing Mb. }\end{array}$ & & $-\frac{\text { M. Mb. }}{\text { L. Mb }}-$ & & M. chert \\
\hline \multirow[t]{4}{*}{ U.Sinian } & \multirow{4}{*}{ 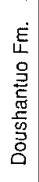 } & Mb.4 & \multirow{4}{*}{$\begin{array}{l}\text { Doushantou } \\
\text { Formation }\end{array}$} & $M b .4$ & \multirow{4}{*}{$\begin{array}{l}\text { Jinjiadong } \\
\text { Formation }\end{array}$} & Ab. 4 \\
\hline & & & & & & Mb. 3 \\
\hline & & Mb. 2 & & Mb.2 & & Mb. 2 \\
\hline & & $\mathrm{Mb} .1$ & & Mb.1 & & Mb. 1 \\
\hline L.Sinian & \multicolumn{2}{|r|}{ Nantuo Formation } & \multicolumn{2}{|c|}{ Nantuo Formation } & \multicolumn{2}{|c|}{ Hongjiang Formation } \\
\hline
\end{tabular}

\section{The Doushantuo Formation}

The Doushantuo Formation accompanied by the Nantuo postglacial transgression is predominated by siliceous carbonates and clastic sediments of restricted platform facies in the central Yangtze platform and its marginal slope, together with P-bearing interbeds or phosphorite deposits, being a total of ca. 60-490 m thick. The strata traditionally assigned to the Doushantuo Formation may be subdivided into 4 lithological members (or successions) in the eastern Yangtze Gorges area. Based on the study of facies and sequence stratigraphy of the type section at Tianjiayuanzi near Liantuo, Yichang (Zhao et al., 1985) and at the representative section at Miaohe, Zigui (Figure 3) (Ding et al., 1996), the lower and middle parts (Members 1 and 2) of this formation here are interpreted to form a highstand transgressive system tract (HST-TST) of 'Sequence 1', following the Nantuo glacigenic sediments. The lower part (Member 1) is composed of ca. $20 \mathrm{~m}$ thick grey or light grey medium-bedded fining-upward microcrystalline or fine-crystalline dolomites with 0.48-7.4 m thick breccia beds in its lowest part, documenting an aggradational deepening upward sequence of nearshore facies conditions. Its base is unconformably overlain on the underlying Nantuo tillites, marked by a paleo-weathered hard crust. The middle part (Member 2) is characterized by dark grey or black thinbedded intercalated shales with laminated medium-bedded siliceous dolomites and micritic limestones and phosphorite nodules totalling ca. $100 \mathrm{~m}$ thick. These beds contain sphaeromorph acritachs, indicating a further deepening and fining upward retrograding sequence and the transition from nearshore to shelf or restricted basin environment. The upper part (Member 3) of the Doushantuo Formation, being only ca. $5 \mathrm{~m}$ thick, is composed of grey or light grey mediumbedded micritic to fine-crystalline dolomites and algal dolomites intercalated with chert beds or concretions, indicating a shallowing upward highstand system tract (HST) of intertidal facies conditions. An abrupt sequence turnover and facies change from highstand light grey medium to thick-bedded microcrystalline dolomites containing sphaeromorph and acanthomorph acritarchs at the top of Member 3 to black thin-bedded silt-shales or shales formed in a TST containing a great abundance of megaalgae, carbonaceous megafossils and softbodied biota at the base of Member 4 of the Doushantuo Formation (the world-famous "Miaohe biota") indicate the presence of a regressive/transgressive event between them, i.e. at the top of 'Sequence 1' consisting of Members 1 to 3 of the Doushantuo Formation. The following transgressive succession identified here as 'Sequence 2' begins with black silty shales at the base of Member 4 and these are characterized by ca. $26 \mathrm{~m}$ thick black siliceous and carbonaceous shales intercalated with thin-bedded muddy dolomites and siltstones containing a great abundance of "Miaohe biota" in the classic Miaohe section on the SW limb of the Huangling Anticline (Steiner, 1994, Ding et al., 1996), but not yet discovered elsewhere. This retrograding deepening upward sequence is in turn overlain by a presumed highstand succession of light grey thick-bedded dolomites at the base of the Hamajing Member of the Dengying Formation. They both form a cycle of 'Sequence 2'. Erdtmann and Wang (1996) have noted that the traditional boundary of the Doushantuo Formation with the Dengying Formation is not an ideal boundary reflecting sequential cycles nor integrated lithological and facies changes. In the NE limb of the Huangling Anticline the 4 lithological members of the Doushantuo Formation may also be recognized at Baiguoyuan in Xinshan County to Zhangcunping in Yichang County (Figure 4). The difference from the Doushantuo Formation at its stratotype section near Tianjiayuanzi, Liantuo is the increase of the P-bearing and K-bearing clastic deposits, because of the vicinity to the "Wudang Oldland" to the north. Otherwise, in the medium to thick-bedded
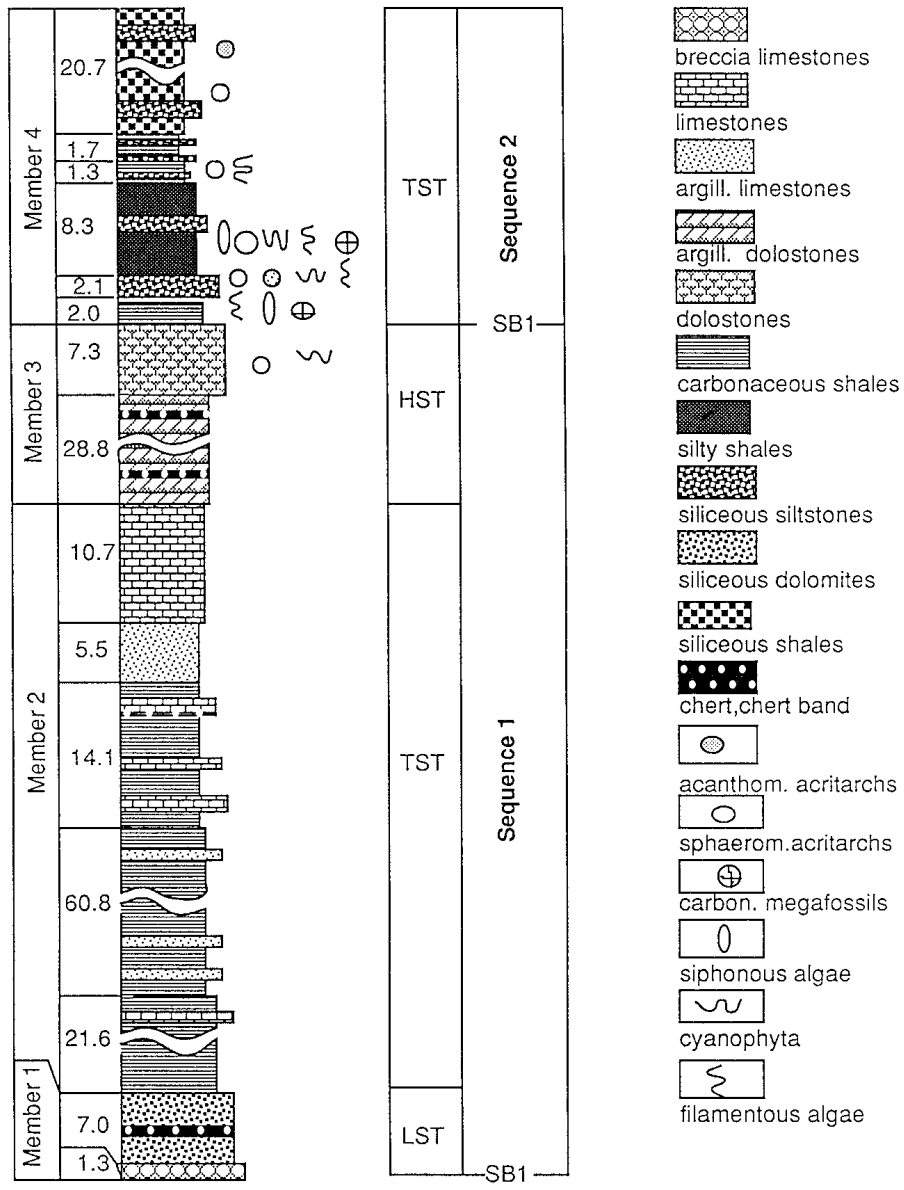

Figure 3 Section of the Upper Sinian Duoshantuo Formation at Diaoyanpo in Miaohe, Zigui County, Hubei. 


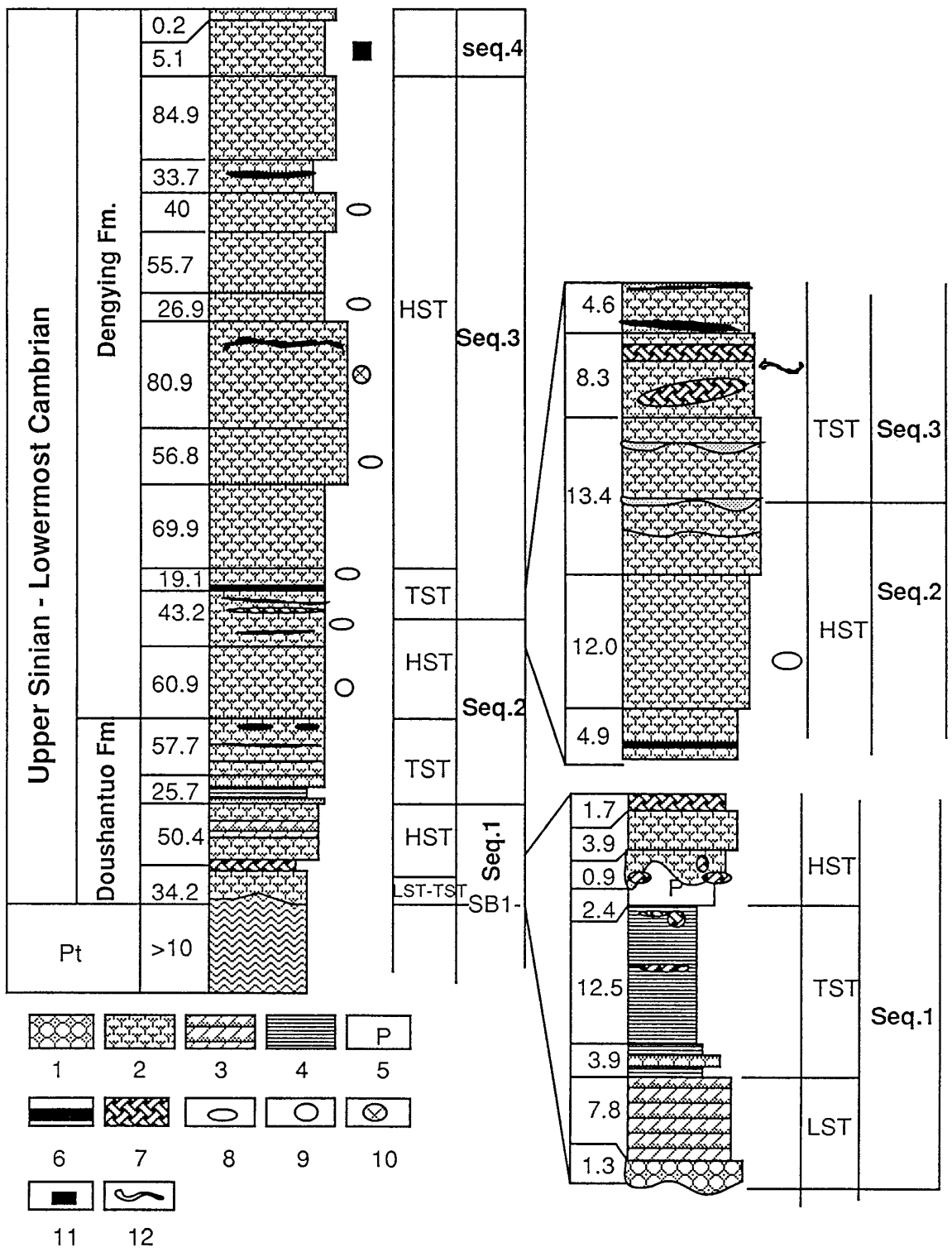

Figure 4 Upper Sinian section at Zhangcunping, Yichang County, Hubei. 1. breccia dolostones 2. dolostones 3. argill. dolostones 4. K-bearing shales 5. phosphorites 6. chert bands or nodules 7. phosphorite deposits 8. birdeye structures 9. oncolites 10. osmotic pisolites 11. shelly fossils 12. cyanophyta.

algal dolomite, which is equivalent to Member 3 containing bird's eye structures, further demonstrates a shallowing upward highstand character. Accompanying the transgression of 'Sequence 2' a largescale $4-17 \mathrm{~m}$ thick phosphorite deposit and a silver-vanadium deposit are present within the black shale intercalated with thin-bedded micritic dolomite and volcanic deposits of Member 4, these probably having been formed in a platform marginal elevated sandbar and lagoon environment.

The Doushantuo Formation in the Jiangnan platform marginal slope facies (SW Hubei-NW Hunan) is similar to that of the central Yangtze platform in its lithological and sequential development, but the lowstand dolomites equivalent to the Member 1 of the Doushantuo Formation in the central Yangtze platform are not present in the Yangjiaping section of Shimen County, NW Hunan and the Zoumaping section of Hefeng, west Hubei (Hunan Bureau of Geology and Mineral Resources, i.e. HBGMR, 1988, Zhao et al., 1988), because of the presence of the Jiangnan island. The base of the Doushantuo Formation there begins with a deepening upward succession consisting of black shales intercalated with dolomites and limestones, which is correlative to Member 2. It is worth pointing out that the ca. $50-130 \mathrm{~m}$ thick grey or dark grey medium-thick intraclast dolomite with oolites, oncolites and collophanites and desiccation crack structures, which are usually put at the top part of the Doushantuo Formation by the above-mentioned authors, covers the underlying interbedded black shales and thin-bedded laminated muddy dolomites. The correlation of lithological and sequence character indicates that the black shales with thin-bedded dolomites in the lower part would represent TST deposits of Member 4, thus starting 'Sequence 2', whereas the overlying intertidal intraclast dolomites of the Hamajing Member, belonging to highstand regressive deposits, now should be moved higher up into the Dengying Formation. This regressive event leading to the sequence turnover from the platform marginal shoal of Member 3 to platform marginal basin of Member 4 is also found at Sancha, Dayong County, Hunan and at Nanshanping, Cili County located along the southern margin of the Jiangnan platform marginal slope. The upper boundary of the Doushantuo Formation, as defined by the HBGMR (1988) and by Yin et al. (1989), should also be moved up into the dolomites with oolites, oncolites and cross-bedding structures of the Lower Dengying Formation, which is documented to be a shallowing upward intertidal sequence succeeding the transgression of 'Sequence 2'.

The succession equivalent to the Doushantuo Formation is called Jinjiadong Formation in central Hunan and eastern Guizhou (HBGMR, 1988). Based on our study of the type section located at Jinjiadong at Muxi near Xupu (Figure 5), the Jinjiadong Formation is predominated by black shales intercalated with dolomites, cherts and phosphatic rocks, being $34 \mathrm{~m}$ thick altogether. The 'Sequence 1' consists again of Members 1 to 3 of the Doushantuo Formation and is easy to be correlated with the latter here. The Member 1 of the Jinjiadong Formation is composed of $8.5 \mathrm{~m}$ thick upward-deepening light
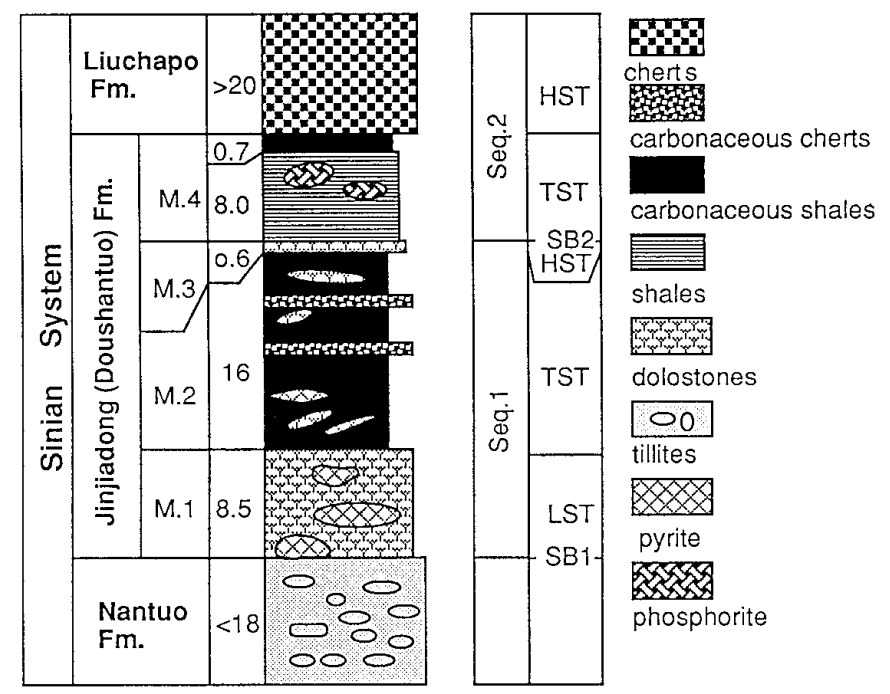

Figure 5 Jinjiadong Formation section at Jinjiadong, Xupu County, Hunan, China. 


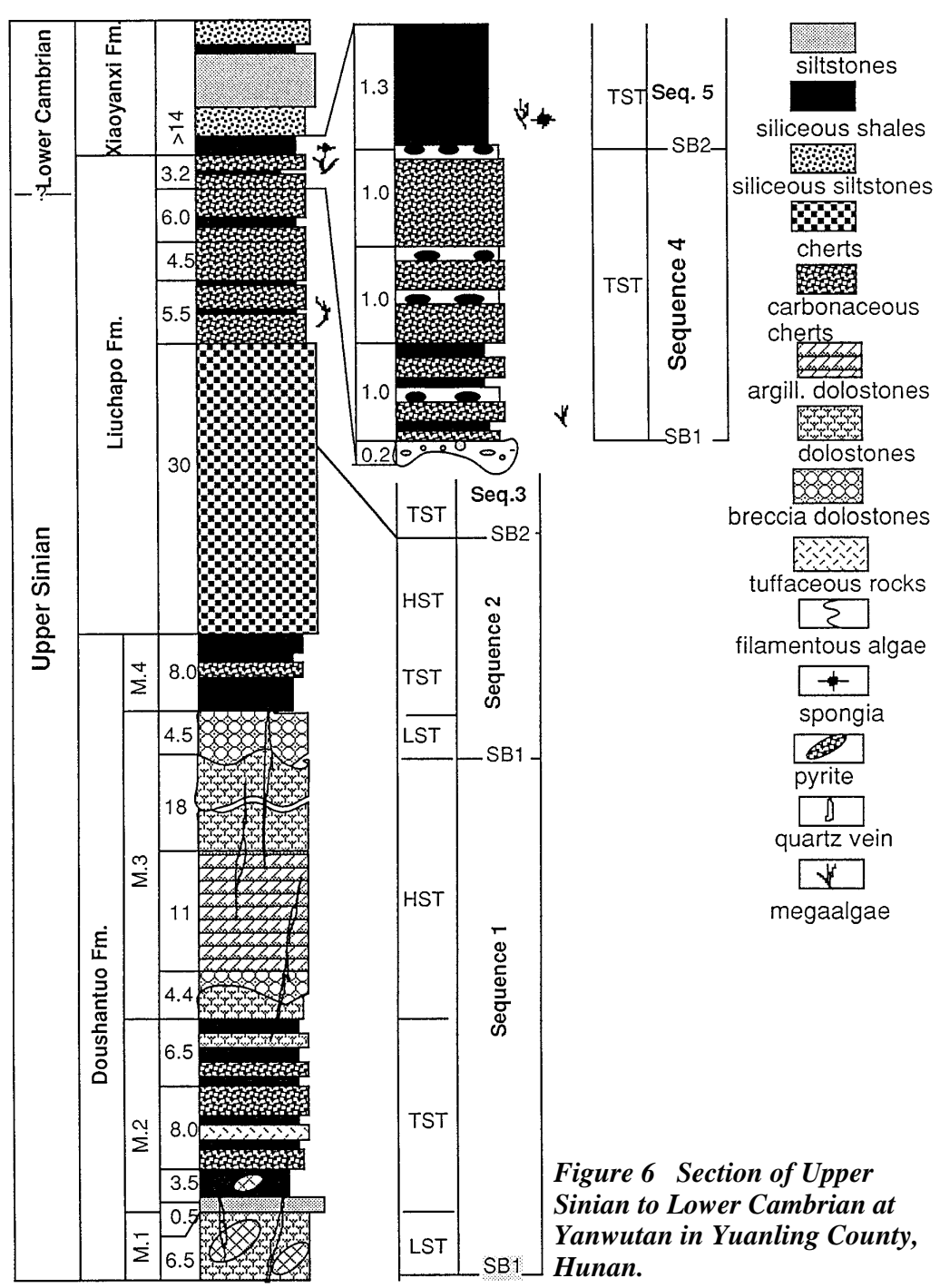

sparitic and arenitic fine-crystalline dolomites with bird's eye structures, cross-bedding and some chert interbeds or nodules at the top. These beds contain sphaeromorph acritarchs, such as Trematosphaeridium, Trachysphaeridium, Lophosphaeridium, etc. The study of the lithological succession indicates that the Hamajing Member reflects a shallowing upward intertidal-supertidal facies, following the transgression of 'Sequence 2' beginning from the base of Member 4 of the Doushantuo Formation. The overlying Shibantan Member of the Dengying Formation is distinctly laminated and is characterized by deepening upward subtidal black thin-bedded fine-crystalline limestones, being rich in organic material, including as well some chert bands and concretions, bearing Ediacara-type fossils such as Paracharnia dengyingi. These ca. $172 \mathrm{~m}$ thick beds contain the 'megaalgae' Vendotaenia (probably sliding bacteria of the family Beggiatoceae) and sphaeromorph acritarchs, etc. The Shibantan Member here is referred to the TST of 'Sequence 3'. This abrupt sequence transition surface from the HST of 'Sequence 2' to the TST of 'Sequence 3' coincides with the boundary of the Hamajing Member with the Shibantan Member and is marked by the appearance of black thin-bedded fine-crystalline limestones with chert nodules, laminated structures and Vendotaenia at the base of Shibantan Member. The Baimatuo Member of Upper Dengying Formation, belonging to the HST of 'Sequence 3' is composed of 453 $\mathrm{m}$ thick light grey and greyish medium to thick-bedded fine-crystalline dolomite with chert bands or concretions and bird's eye structures, this probably indicating intertidal to supratidal conditions. The Baimatuo Member contains possible sparse megaalgae or 'worms' Sinotubulites and trace fossils Skolithus as well as sphaeromorph acritarchs (Zhao et al., 1988). The succeeding transgressive system tract of 'Sequence 4', which is placed in the Tianzhushan Member at the top of the Dengying Formation, is composed of grey micro- to fine-cystalline laminated dolomites and argillaceous dolomites in the lower part and of grey phosphorite-bearing rudaceous and arenaceous siliceous limestone-dolomites in the upper part. This member is 3-3.4 m thick at Tianzhushan and Liantuo,

grey dolomites with pyrite lenses, unconformably overlying the Nantuo tillites. The Member 2 is characterized by ca. $10 \mathrm{~m}$ thick black shales with interbeds of phosphate beds, documenting a TST character. The Member 3, referred to the regressive highstand sequence, is composed of $0.6 \mathrm{~m}$ thick dolomite at the Jinjiadong section, due to the uplift of an island arc in the south. From the Yanwutan section, Yuanlin County further north, relatively far away from the island arc, this regressive sequence is indicated by $37.9 \mathrm{~m}$ a thick deposits coarsening upward from argillaceous to intraclastic dolomites (Figure 6). The Member 4, beginning with the transgression of 'Sequence 2', is characterized by $8 \mathrm{~m}$ thick black shales in the lower and middle parts and $0.7 \mathrm{~m}$ thick black cherts in the upper part at the Jinjiadong section, showing a deepening upward sequence. This transgressive tract is also present in the Yuanling and Qianyang area (Figure 8), but is not found at Xinghuang, western Hunan, close to the border of Hunan with Guizhou. The deposits correlative to the 'Sequence 1' of the Doushantuo Formation are probably missing there (Figure 7). The possible Member 4, accompanying the trangressive expansion of 'Sequence 2', consists of ca. $13 \mathrm{~m}$ thick grey argillaceous dolomites in the most part and $0.5 \mathrm{~m}$ thick dolomites with phosphorite lenses in the top beds.

\section{The Dengying Formation}

The Dengying Formation, with the section of Dengying Gorge, near Yichang as a stratotype, traditionally comprises four lithological members (Figure 9) : The Hamajing Member in the lower part consists mostly of $172 \mathrm{~m}$ thick grey medium-thick-bedded oncolite,

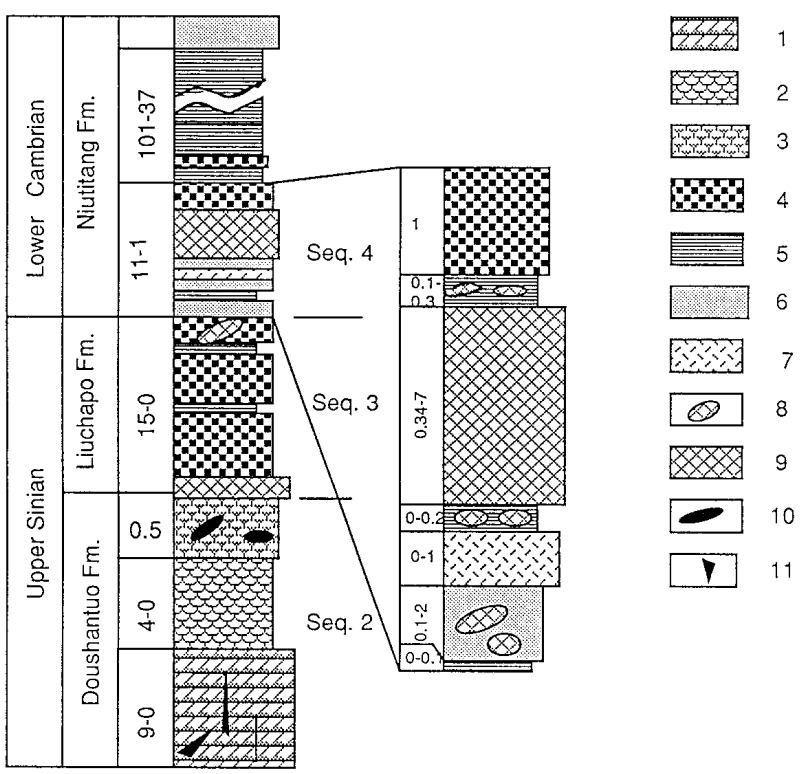

Figure 7 Section of Upper Sinian to Lower Cambrian of the Gongxi barite deposits in Xinghuang County, Hunan, China. 1. dolostone with chert nodules 2. argillaceous dolostones

3. dolostones 4. black cherts 5. black carbonaceous shales

6. black siltstones 7. tuffaceous cherts and tuffs 8 . barite lenses 9. barite orebody 10. phosphorite rock 11. quartz veins. 


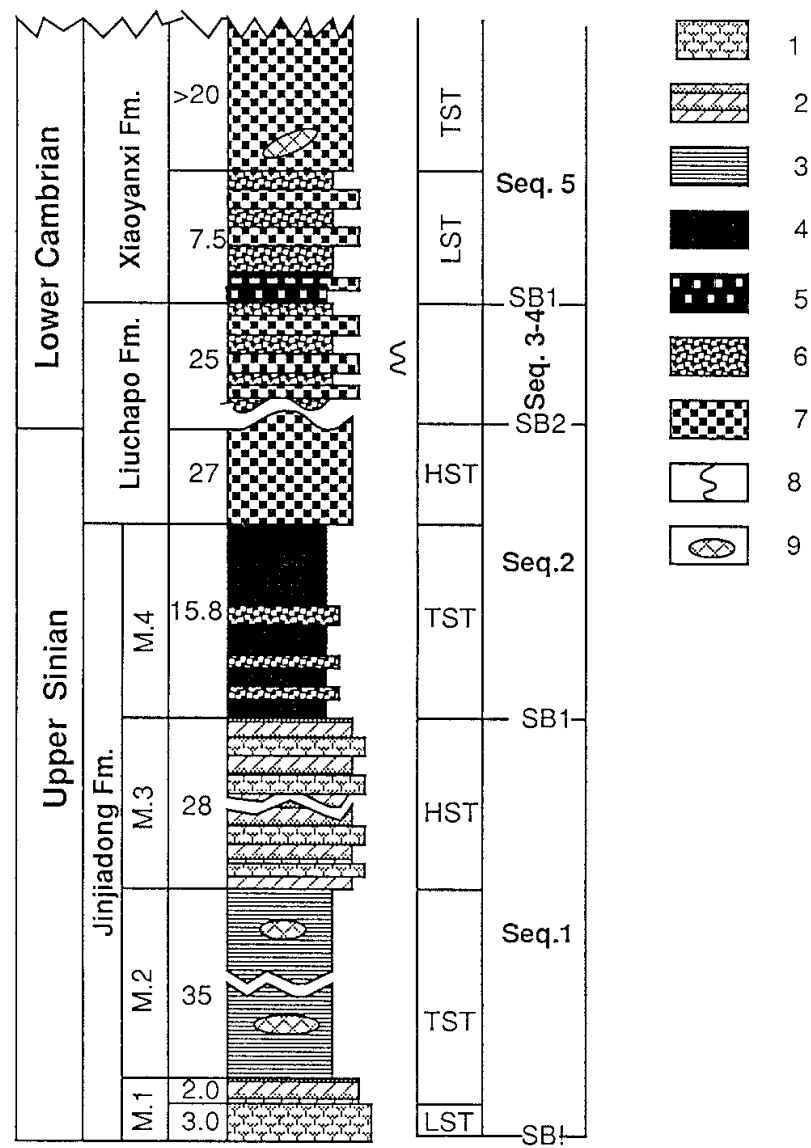

Figure 8 Section of Upper Sinian to Lowermost Cambrian at Shuangxi in Qianyang County, Hunan, China. 1. dolostones 2. argillaceous dolostones 3. shales 4. carbonaceous shales 5. silty shales 6. siliceous shales 7. cherts 8. filamentous algae 9. phosphorite.

near Yichang, containing trace fossils Planolites and Skolithus in the lower part and small shelly fossils such as Anabarites trisulcatus, Protohertzina, Hyolithellus, monoplacophorans, gastropods and chancellorides in the upper part, being probably equivalent to Zone 1 of the Meishucun Stage (Brasier, 1989). The TST or condensed deposits of 'Sequence 4' are distinguished from the oncolites and algal dolostones of HST of 'Sequence' by a bed of siliceous hardground at the top of the Baimatuo Member. Its top is truncated abruptly and is overlain by black carbonaceous shales of the Shuijingtuo Formation with the trilobites of the Tsunyidiscus Zone. A obvious hiatus between the Tianzhushan Member and the Shuijingtuo Formation is marked by an unconformable boundary surface and the mixture of biological assemblages equivalent to Zones 1 and 2 of the Meishucun Stage in the Upper Tianzhushan Member, which is probably a result of the regression event beginning at the upper Tianzhushan Member. This regressive/transgressive turnover event occurring between the Tianzhushan and Baimatuo Members, is obviously reflected within the interplatform basin, such as at the Yanjiahe section, near Baishuiyan, Yichang County. The dolomites of the Tianzhushan Member there are replaced by black shales with interbeds of limestones or large limestone concretions. The Dengying Formation in the Jiangnan platform marginal slope facies from the Yangjiaping section, Shimen County to the Sancha, Dayong County and Nanshanping, Cili County, Hunan is similar to that of the eastern Yangtze Gorges in lithological and sequence development. The distinction from the latter is the decrease in thickness and the increase of oolitic, oncolitic and cross-bedding structures, in stromatolites and rudaceous contents in the dolomites of the lower Dengying Formation and in the appearance of a number of slump structures or breccia beds in dolomites of the Upper Dengying Formation, reflecting intertidal sediments in the $\mathrm{p}$ !atform marginal shoal to slope zone in the vicinity of an island arc.

The strata equivalent to the Dengying Formation are called Liuchapo Formation in the back-arc basin of central Hunan and E. Guizhou. The type section is located at Liuchapo near Anhua in central Hunan. In the type locality the Liuchapo Formation is composed of grey or light grey thick-bedded cherts in the lower part, and thinto medium-bedded cherts with white and black bands in the middle, and black thin-bedded laminated cherts intercalated with black shales in the upper part (Yin et al.,1989). At the type section this formation is $87 \mathrm{~m}$ thick. The Liuchapo Formation exposed at Yanwutan, Yuanling County, at Tongpenggai (Gongxi in Figure 1), Xinghuang County and at Shuangxi, Qianyang County (Figures. 6-8) is characterized by the distinctive development of gravitational slumps. The sequence analysis indicates that the lower and middle parts should be correlated with the Hamajing and Shibantan Members of the Dengying Formation, respectively. The lower Liuchapo Formation probably represents highstand development succeeding the TST of the Member 4 of the Doushantuo Formation (or of the coeval Jinjiadong Formation), whereas the Middle Liuchapo Formation is characterized by a deepening upward transgressive succession, which is indicated by thinning upward single bedding forms and an increase of laminated structures, this being considered to be equivalent to the Shibantan Member consisting of the TST of 'Sequence 3' in the Yangtze platform, although the demarcation for a sequence division is not clear in this constantly subsiding basin. However, the increase of $\delta^{30} \mathrm{Si}$ values, given as $0.1-0.3$ for the Lower Liuchapo Formation to 0.5-0.7 for the Middle Liuchapo Formation (Peng et al., 1995), reveals the change from shallowing upward to deepening upward at the Yanwutan section. A sequence turnover was found between the lower and upper parts in the Upper Liuchapo Formation at the Yanwutan section (Figure 6) and marked

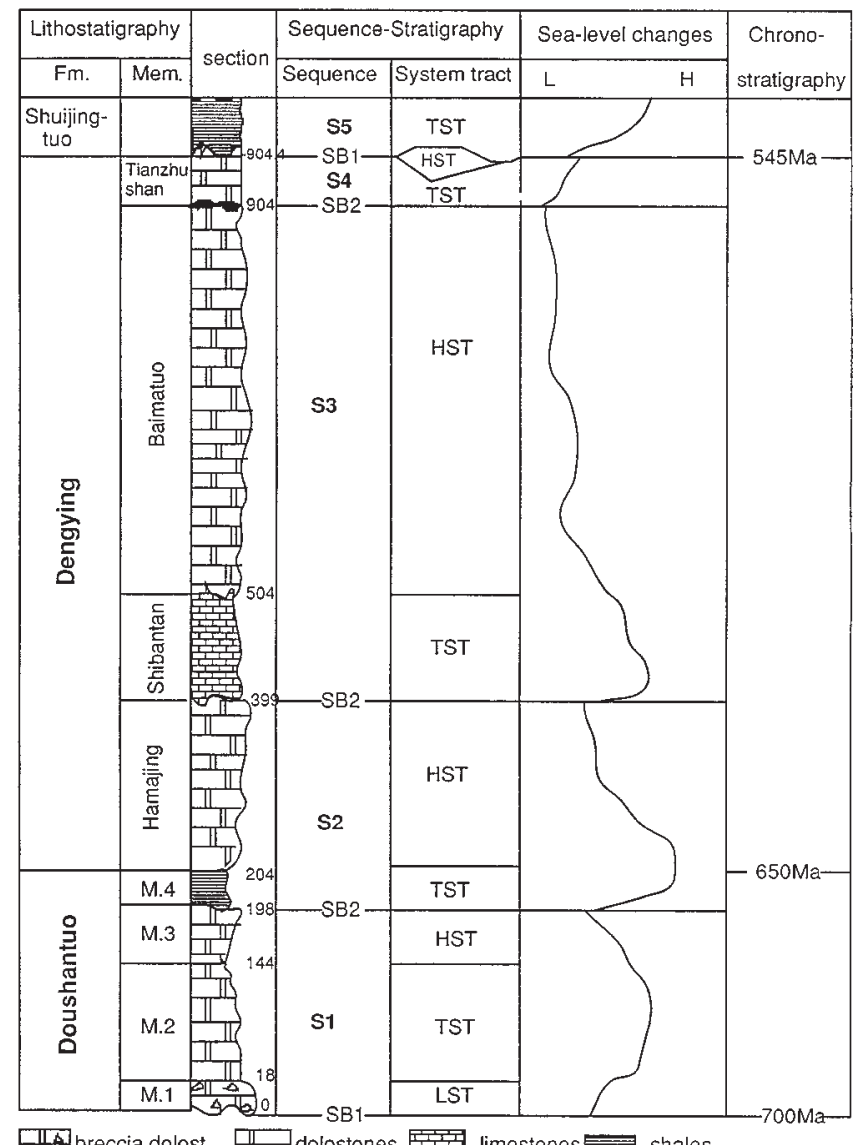

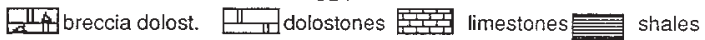

Figure 9 Section of the post-glaciation to Lowermost Cambrian sequence at Dengying Gorge near Yichang. 


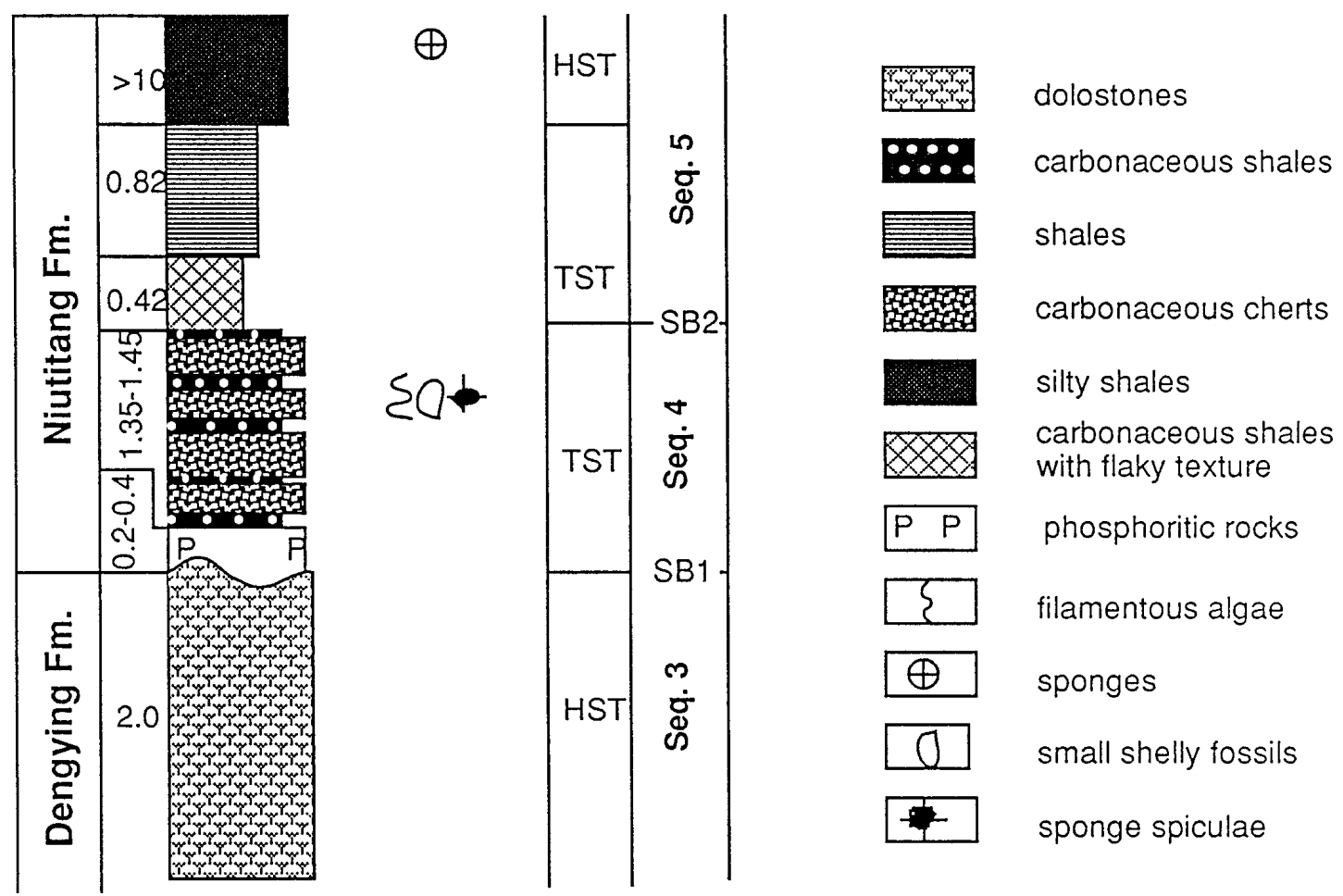

Figure 10 Section of uppermost Sinian to lowermost Cambrian sequence at Sancha in Dayong County, Hunan.

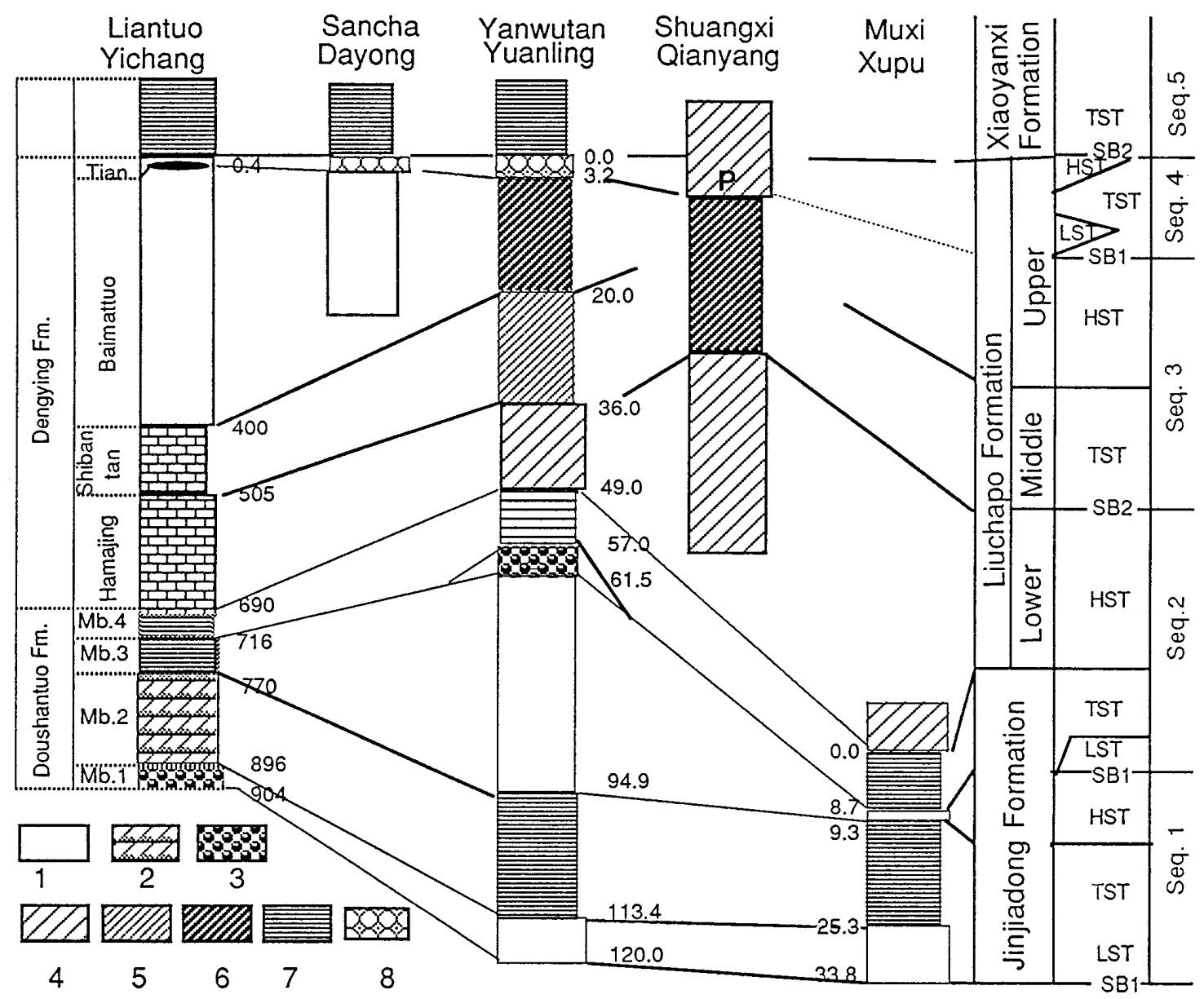

Figure 11 The correlation of litho- and sequence-stratigraphic units. 1. dolomites 2. muddy dolomites 3. dolomitic breccia 4. thickbedded cherts 5. thin-bedded cherts 6. cherts intercalated with shales 7. shales 8. P-bearing "black rock series". 
by a $0.2 \mathrm{~m}$ thick breccia underlain in the black shales with phosphorite concretions of horizontal distribution and vendotaenids, $3.2 \mathrm{~m}$ below the boundary of the Liuchapo and (Lower Cambrian?) Xiaoyanxi Formations at Yanwutan. This breccia overlies the underlying $16 \mathrm{~m}$ thick thin-bedded cherts, which are intercalated with black shales at the line between the Lower and Upper Liuchapo Formations. Hence, the lower part of the Upper Liuchapo Formation is interpreted as a highstand deposit of 'Squence 3', equivalent to the Baimatuo Member of the Dengying Formation. Succeeding transgressive deposits occurring in the topmost Liuchapo Formation (upper Upper Liuchapo Formation) are likely equivalent to 'Sequence 4' consisting of black shales of the Yanjiahe Member at the top of the Dengying Formation. Accompanying the sequence turnover the $\delta^{30} \mathrm{Si}$ values decreased and depletion of Ce obviously increased from the lower to the upper parts in the Upper Liuchapo Formation. This may also reflect the changes of depositional environments from reducing conditions in the lower part to oxygenic (possibly dysaerobic) conditions in the upper part at the Yanwutan section (Yin et al., 1996, Peng et al., 1995). The HST deposits, equivalent to the Upper Tianzhushan Member, containing small shelly fossils, may be difficult to be recognized there due to the paleogeographic position near the basin center. The succeeding transgression, referred to 'Sequence 5' herein, is characterized by the incoming of siliceous carbonaceous shales with sponge spiculae and vendotaenids at the base of Xiaoyanxi Formation and probably correlates with the transgressive deposits starting at the base of the Shuijingtuo Formation. At the Sancha section, Dayong County, near the NW margin of this back-arc basin (Figure 10), the sequence change between 'Sequence 3' and 'Sequence 4' is indicated by the incoming of a lowstand $0.2-0.4 \mathrm{~m}$ thick phosphorite bed at the base of the Niutitang Formation which unconformably overlies the grey siliceous and karsted dolomites of the Dengying Formation. The following transgressive deposits are composed of 1.35-1.45 m thick black thin-bedded cherts intercalated with black shales containing Perspicaris sp., fragments of vendotaenids and scattered sponge spiculae, this being possibly equivalent to the $3.2 \mathrm{~m}$ thick black shales and cherts at the topmost Liuchapo Formation at the Yanwutan section or to the Tianzhushan Member at the top of the Dengying Formation in the platform facies of the Yichang area. The overlying black carbonaceous shales, being $0.24 \mathrm{~m}$ thick at the Sancha section, are weathered to a flaky texture, probably correlate with the base of the Shuijingtuo Formation near Yichang. In the Shuangxi section of Qianyang County the sequence transitional surface equivalent to the one between 'Sequence 3' to 'Sequence 4' is hard to be recognized in the top Liuchapo Formation because its paleogeographic position was also close to the basin center (Figure 7), but the change of the Ce-anomaly from 0.38 to 0.69 and then to 0.41 , obtained from the cherts of the topmost Liuchapo Formation, the basal Cambrian Ag$\mathrm{V}$ deposits and the Ag-V deposits of the lowest Xiaoyanxi Formation, respectively, reveal that the seawater in the topmost vendotaenid-bearing Liuchapo Formation was deeper than that of the basal Xiaoyanxi Formation. This would document a shallowing upward highstand sequence in the topmost Liuchapo Formation, and a deepening upward lowstand environment with the gradual decrease of the Ce-anomaly in the overlying lowest Xiaoyanxi Formation, of which the base begins with the Ag-V deposits. This lowstand environment is probably absent at Yanwutan. The succeeding transgression at the Shuangxi section is marked by the incoming of black siliceous shales with phosphorite concretions and Vendotaenids, which is thought to be equivalent to the 'Sequence 5' started at the base of the Xiaoyanxi Formation at Yanwutan. At the Tongpenggai (Gongxi in Figure 1) section, in the south of Xinghuang County, closer to the uplift of Central Guizhou (Figure 8), the regression of the topmost Liuchapo Formation leads to the absence or incomplete development of 'Sequences 3 and 4 ' in association with the occurrence of a largescale slumping event. The 'Sequence 1' equivalent to most of the lower Doushantuo Formation is probably also missing there. The transgressive succession equivalent to 'Sequence 5' there starts with the incoming of black shales bearing barite deposits at the base of the Cambrian Niutitang Formation. The overlying shales yield sponge spicule everywhere. The base of the Niutitang Formation is probably a bit lower than the Sancha section, since the boundary of the Niutitang Formation with underlying strata (Dengying or Liuchapo Formation ) is diachronous with the expanding transgression of 'Sequence 5'.

Summing up the study of litho- and sequence stratigraphy of these five sequences, altogether three major grand cycles may be recognized during the interval between the post-Nantuo deglaciation dated at ca. $700 \mathrm{Ma}$ to the earliest Cambrian at ca. $545 \mathrm{Ma}$. The relationship with equivalent lithological units at the respective localities in the provinces of Hubei and Hunan is shown in Table 1 and Figure 11.

\section{Biostratigraphy}

During the interval from the Nantuo post-glacial deposits to the earliest Cambrian, 4 major biotic groups or biological events can be recognized in the studied region.

\section{The Miaohe biota}

The Miaohe biota occurring in the black siliceous shale of the Member 4 of the Doushantuo Formation at the Miaohe section, Zigui, Hubei (Chen and Xiao, 1991 , Ding et al., 1996, Steiner, 1994), with the second transgression after the Nantuo deglaciation, is characterized by the incoming of sphaeromorph acritarchs, acanthomorph acritarchs, nematomorph acritarchs, megaalgae and siphonous megaalgae with a great abundance and diversity and some carbonaceous megafossils, trace fossils as well as some (questionable) softbodied metazoans (Ding et al., 1996). The systematics and taxonomy of the Miaohe biota are under studying and are considered to be controversial at the present stage of investigation. However, the occurrence of a number of well-preserved megaalgae with primitive 'root' structures and possible sponge spicule (Ding et al., 1996) as well as some possible floating acanthomorph and sphaeromorph acritarchs indicates that these biota may probably have inhabited low-energy intraplatformal depressions of shallow water. This particular ecological condition, caused by a transgression following the regressive event between Members 3 and 4 of the Doushantuo Formation, in the depression of the central Yangtze platform, may serve as an explanation why these biota may not be present in coeval strata formed in intertidal to supratidal environments in the NE limb of the Huangling Arch. The base of the Doushantuo Formation is dated at 700 Ma by the Rb-Sr method (Ma et al., 1984), whereas its top age is at ca. 650 Ma (Zhao et al.,1988, Ma et al., 1984). The age of Miaohe biota, therefore, are obviously older than the Ediacaran Vendobiota.

\section{The "Xilingxia biota"}

The name of "Xilingxia fauna" given by Chen et al. in 1981 is used to express the Ediacara-type soft bodied metazoans found in the Dengying Formation with a provisional radiometric date of ca. 650545 Ma. The representative elements include Sinotubulites, Paracharnia, sponge spicule (Zhao et al., 1988) and cf. Sabellidites (Tang et al., 1978). It is worth mentioning that the strata in which cf. Sabellidites with Chinochaetopterus and sponge spicule were found in Yuanling, Hunan should be correlated with the Tianzhushan Member of earliest Cambrian age, but then Pre-Cambrian. Chinochaetopterus and cf. Sabellidites, identified by Tang et al. (1978), are likely to be of vendotanids rather than of soft-bodied metazoan derivation. The fossil association of this stratigraphic interval are here characterized as the so-called "Xilingxia fauna". In fact, this 'fauna' is charaterized by the incoming of Vendotaenia antiqua with a great abundance and sparse (a single specimen) Ediacaratype Paracharnia, and Sinotubulites, sponge spicule, Chuaria-like fossils, and mainly found in the Shibantan Member of the Dengying Formation. The term "Xilingxia fauna", therefore, is not to be applied as strictly, as these biota being approximately coeval with 
the Ediacara 'Fauna' of Australia or the Vendian biota of European Russia in age. The megaalgale association represented by Gesinella and Longifuniculum reported from the Middle Liuchapo Formation of Wenshanwan, Hunan (Steiner, 1994) is likely equivalent to the Vendotaenia antiqua assemblage of the Shibantan Member in stratigraphic position .

\section{Multiphyletic "small shelly fossils"}

There is no universally correlatable stratotype nor GSSP for the Precambrian-Cambrian boundary as yet. In the studied region the Precambrian (Sinian)-Cambrian boundary is normally biostratigraphically defined between the Tianzhushan Member and the Baimatuo Member in the Yangtze Platform (Zhao et al., 1988) or between the Niutitang and Dengying Formations in the Jiangnan marginal slope (HBGMR, 1988) on the basis of small shelly fossils and their correlation with that of Meishucun section, Yunnan. In the back-arc basin of central Hunan and eastern Guizhou, the Sinian-Cambrian boundary is defined between the Liuchapo and Niutitang (or Xiaoyanxi) Formations with certain doubts due to absence of sufficient fossil evidence. In comparing with the small shelly fossil assemblage at the Meishucun section the multiphyletic small shelly fossils found in the Upper Tianzhushan Member show an admixture of Assemblage Zone (A. Z.) 1, e.g. Anabarites-Protohertzina A. Z. with those elements typical of A. Z. 2, such as Paragloborites, Siphonuchites, probably caused by the regressive events between the 'Sequences 4 and 5'. In the south of Huangling Arch the Yanjiahe Formation, formed in the platformal depression, is composed of ca. $35 \mathrm{~m}$ thick black shales which include interbeds of limestones or large calcareous concretions. Two small shelly fossil assemblages seem to be recognized there: the Anabarites-Protoherzina A. Z. in the lower part with sparse Circotheca and the Paragloborites-Siphonuchites A. Z. in the upper which contains monoplacophorans and gastropods (Chen, 1984), this being best correlated with the A. Z. 1 and A. Z. 2 of the Meishucun section in Yunnan, respectively. In the Jiangnan shelf-slope the earliest Cambrian small shelly fossils were only reported from the base of the Niutitang Formation at Yangjiaping, Shimen County, an area that belonged to the platformal marginal shelf region during that time. Due to the southward deepening seawater along with the transgression of 'Sequence 4', small shelly fossils are probably replaced by the assemblage of Perspicaris, vendotaenids and sponge spiculae in the coeval black shales, overlying the ca. 0.2-0.4 m thick lowstand phosphorite deposits at the base of the Niutitang Formation at Sancha, Dayong. In the relativey more shallow platform marginal slope, such as at Dapu of Cili County, some small shelly fossils occur in the equivalent black carbonaceous shales. No small shelly fossils would be present in the relatively deeper back-arc basin. Sequence correlation suggests that the vendotaenids and sponge spiculae found in the topmost Liuchapo Formation ('Sequence 4') probably are correlative with the earliest Cambrian small shelly fossils as far as the stratigraphical horizon is concerned. The boundary of Liuchapo Formation and the Niutitang Formation there is approximately equivalent to the boundary of Tianzhushan Member and Shuijingtuo Formation.

\section{Occurrence of trilobites}

The earliest trilobites in association with hyolithids and sponge spicules, representing the Tsunyidiscus Zone, are found in the black shales with the thin-bedded limestone interbeds in the lower Shuijingtuo Formation, $2.8 \mathrm{~m}$ above the bottom of this formation i.e.. at the transition surface of 'Sequence 4' with 'Sequence 5' in the stratotype section of Liantuo, Yichang (Figure 9). A major hiatus is present between the Shuijingtuo Formation and the Tianzhushan Member, indicated by $2.8 \mathrm{~cm}$ thick of yellowish strongly ferruginous clay ('boundary clay'). The base of the Shuijingtuo Formation there may only be correlated with the Middle Qiongzhusi Stage of the Meishucun section in Yunnan. In the Yanjiahe and Jijiapo (Yichang), Heziao (Changyang) and at Miaohe (Zigui) sections along the SW limb of the Huangling Arch there are ca. 15-30 m thick black car- bonaceous shales with lenticular P-bearing limestones and dolomitic limestones beneath the beds containing Tsunyidiscus. This part of black shales may be equivalent to the Lower Qiongzhusi Stage. Obviously, the sequence transition surface between 'Sequence 4' and 'Sequence 5 ' in these sections is lower than that found at Liantuo and is marked by an abrupt change of rock succession from limestone at the top of the Yanjiahe Formation to black shales at the base of the Shuijingtuo Formation and a bed of brecciated or oolitic limestone between them. Along the northern margin of the Jiangnan slope area the earliest trilobite represented there is Hunanocephalus together with sponge spicules, which is found in the lower Niutitang Formation at the Yangjiaping section of Shimen County, Hunan. The layer containing trilobites there is only equivalent to the HunanocephalusHubeidiscus Zone in the Upper Shuijingtuo Formation. No trilobite has been found in the lowest Xiaoyanxi Formation in the Xiang-Qian back-arc basin until now. However, the sequence correlation suggests that the black shales of the lowest Xiaoyanxi Formation containing numerous phosphorite concretions, vendotaenids and rare sponge spicules at the Yanwutan section (Yuanling county), or of the Mo-Ni deposits at the Sancha section (Dayong) would be directely correlated with the same transgressive beds of 'Sequence 5', and roughly correlated with the lowest Shuijingtuo Formation of the Yangtze platform, even though their basal boundary between them is not fully equivalent to each other due to the diachronous northward advance of this transgression. The underlying black cherts of the topmost Liuchapo Formation sometimes contain vendotaenids and could be correlated with the Tianzhushan Member or Yanjiahe Formation (the latter containing vendotaenids) of the platformal facies region.

\section{Approaches to chemostratigraphy}

The occurrence and distribution of the above mentioned four main biotic assemblages from the Nantuo post-glaciation to the earliest Cambrian is basically related to the special environment and biofacies differentiation of the "black rock series" (shales, cherts, limestones and dolomites, all or parts being associated with phosphorites) formed during several micro- and macrocycles of transgressions, followed by regressive events .

A traditional explanation concerning the paleooceanic environments of these "black rock series" is related to greenhouse or anoxygenic events in a deep and reducing basin, but this is not fully consistent with the observations and evidences we collected and analysed. During the Nantuo post-glaciation to Early Cambrian the "black rock series" appears cyclically in the studied region altogether five times and all are related to transgressions successively following 5 regressive events, which are each documented by erosional disconformities or sequence turnover, and the TSTs are characterized by relatively higher organic matter contents together with some fossils including primary 'gigantic' prokaryotic 'cell aggregates' to the earliest trilobites and by the P-bearing nodules or deposits, indicating shallow and probably ventilated environments. Study of REE data of 4 samples collected from "Miaohe biota"-bearing black shales in the Member 4 of the Doushantuo Formation by Ding et al. (1996) indicates that $\mathrm{Ce}$ and Eu separately vary between $0.57-1.01$ and 0.69-0.89. Both REE indices have not shown a clear depletion or enrichment signal as Ding et al. (1996) reported. The Ce-anomaly as an indicator of oxygen and redox conditions is mainly controlled by the oxygen-redox potential and by $\mathrm{Ph}$ variations of original seawater environment. No distinct Ce-anomaly was obtained from the black shales of the Doushantuo Formation. This may reveal that the black shales were not formed under reducing conditions, thus soluble $\mathrm{Ce}^{3+}$ was transformed into insoluble $\mathrm{Ce}^{4+}$ sinked into the sediments under oxygenic conditions. A correlation of the REE distribution curve of the black shales with the standard one shows that the MREE yields a slight enrichment, but the LREE and HREE a slight depletion. This distribution pattern is different from the standard pattern of shales from seawater of recent ocean and also from that of the 
shales collected from chert nodules of the shallow-water carbonate platform. It is imagined that the black siliceous shales containing the Miaohe biota were probably formed in a semi-restricted shallow depression of intraplatform type with normal salinity. It was probably affected at the same time by both seawater and fresh water. Study of carbonaceous cherts of Member 2 of the Doushantuo Formation and of the uppermost Liuchapo Formation with vendotaenids and of the base of the Xiaoyanxi Formation, separately collected from the Yanwutan section (Yuanling) and from the Shuangxi section (Qianyang) by applying the REE method, shows that the Ce depletion would exhibit a progressive increasing trend from 0.94 at the base to 0.40 at the top of the Liuchapo Formation with light fluctuation in the middle, and then a decrease to 0.51 at the base of the
$\mathrm{CaO}+\mathrm{MgO}(1.3-3.5 \%)$ and $\mathrm{A}_{2} \mathrm{O}_{3}+\mathrm{K}_{2} \mathrm{O}$ contents $(3.2-13.5 \%)$ would, in fact, prediagenetically have been a transitional rock type of dolomite-mudstone-chert, that the black cherts of the topmost Liuchapo Formation containing relatively high $\mathrm{SiO}_{2}(75-97 \%)$ and normal $\mathrm{A}_{2} \mathrm{O}_{3}+\mathrm{K}_{2} \mathrm{O}(0.5-4.2 \%)$ was actually a transitional rock of chert-argillaceous chert, and the black rock beds of the basal Xiaoyanxi Formation containing relatively high $\mathrm{A}_{2} \mathrm{O}_{3}+\mathrm{K}_{2} \mathrm{O}$ (1.3-9.8\%) and low $\mathrm{CaO}+\mathrm{MgO}(<2 \%)$ prediagenetically was a transitional rock of carbonaceous shale to chert, even though the colours of all these rock types are distinctly black (Table 2 ).

The Nantuo post-glacial to earliest Cambrian "black rock series" in the Jiangnan platformal slope and Xiang-Qiang back-arc basin are interpreted to have been formed originally in an oxidizing

Table 2 Chemical composition of the "black rock series".

\begin{tabular}{|c|c|c|c|c|c|c|c|c|c|c|c|}
\hline NO & Name & $\mathrm{SiO}_{2}$ & $\mathrm{TiO}_{2}$ & $\mathrm{~A}_{2}{ }_{2} \mathrm{O}_{3}$ & $\mathrm{TFe}$ & $\mathrm{CaO}$ & $\mathrm{MgO}$ & $\mathrm{K}_{2} \mathrm{O}$ & $\mathrm{Na}_{2} \mathrm{O}$ & $\mathrm{P}_{2} \mathrm{O}_{5}$ & $\mathrm{MnO}$ \\
\hline 1 & chert & 75.2 & 0.90 & 9.74 & 5.22 & 0.22 & 1.13 & 3.72 & 0.04 & 0.04 & 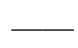 \\
\hline 2 & chert & 88.4 & 0.08 & 2.29 & 1.80 & 1.68 & 1.38 & 0.85 & 0.03 & 0.03 & 0.07 \\
\hline 3 & chert & 92.1 & 0.03 & 0.49 & 2.03 & 0.14 & 0.08 & 0.09 & 0.01 & 0.07 & 0.02 \\
\hline 4 & chert & 97.7 & 0.05 & 0.57 & 0.73 & 0.17 & - & 0.14 & - & 0.01 & 0.03 \\
\hline 5 & chert & 75.3 & 0.14 & 2.00 & 1.45 & 0.04 & 0.35 & 0.41 & 0.01 & 0.71 & 0.08 \\
\hline 6 & chert & 87.1 & 0.23 & 2.9 & 3.82 & 0.55 & 0.87 & 1.27 & 0.04 & 0.14 & 0.05 \\
\hline 7 & chert & 83.3 & 0.06 & 1.22 & 2.19 & 0.08 & 0.07 & 0.09 & 0.01 & 0.06 & 0.02 \\
\hline 8 & chale & 67.1 & 0.47 & 8.53 & 3.88 & 0.41 & 1.05 & 1.32 & 0.03 & 1.71 & 0.01 \\
\hline
\end{tabular}

1-2: Jinjiadong Formation, 3-6: Liuchapo Formation, 7-8: Xiaoyanxi Formation.

Xiaoyanxi Formation containing the P-bearing nodules. The trend change of the Ce-anomaly appears to correspond to the transgression and regression cycles of 'Sequences 3 to 5', especially between the 'Sequence 4 and 5', i.e. between the Liuchapo and Xiaoyanxi Formations. A similar change of the Ce-anomaly occurs between the black cherts at the topmost Liuchapo Formation containing Ag-V deposits and the overlying carbonaceous cherts with vendotaenids at the base of the Xiaoyanxi Formation in the Shuangxi section (Qianyan). The former is dated at 0.69 and the latter is ca. 0.4. The progressive increase of the Ce depletion appears to coincide with the transgressive expansion of 'Sequence 5'. On the other hand, the above mentioned black cherts of the Liuchapo formation all show a positive Euanomaly except for those samples from the lowest Xiaoyanxi Formation. This may indicate that these Liuchapo cherts were formed in relation to the hydrothermal activities which appeared during their diagenesis (Klinkhammer et al., 1983). This result is in good accordance with the study of silicon and oxygen isotope compositions of the Liuchapo Formation from this area (Peng et al., 1995). The $\delta^{30} \mathrm{Si}$ values are $0.0-0.7$, and $\delta^{18} \mathrm{O} 20.2-23.6$, showing that the silicaforming chert was derived from hot water. The obvious slumping structures found in the Liuchapo Formation at Yuanling, Qianyang and at Xinhuang further indicate the presence of tectonic-thermal events during the pre-dewatering diagenesis, especially of the claysupported sediments. IR-spectroscopic study of dispersed organic matter, separately collected from the black cherts and shales of the Liuchapo and Xiaoyanxi Formations of the above mentioned section indicates a quite high vitrinite reflectance equivalent $(\mathrm{RoE})$ varying between $2.5-3.55 \% \mathrm{RoE}$. This also shows the influence of a later tectonic-thermal activity on these black cherts and shales. The study of the chemical composition of the "black rock series", which was individually sampled from the Doushantuo (Jinjiadong) Formation (Member 2), from the topmost member of the Liuchapo Formation and from the base of the Xiaoyanxi Formation at Yanwutan (Yuanlin) and Shuangxi (Qianyang), suggests that the black shales of the Doushantuo Formation (Member 2) containing a relatively high transgressive environment. The black siliceous dolomites of Member 2 of the Doushantuo Formation are usually an onlap on the dolomite of Member 1 with transgression of 'Sequence 1'. Accompanying the transgression of 'Sequence 3', two to three thin beds of siliceous breccias are found near the topmost Liuchapo Formation at the Yanwutan section. In the Jinjiadong section near Xupu and in the type Liuchapo section at Anhua some current and lenticular bedding forms are observed within the Liuchapo Formation. These high energy beds demonstrate that the black cherts of the Liuchapo Formation have clearly not been formed in a deep-water reducing environment. The lowest Cambrian black shales are characterized by the incoming of Perspicaris and of sponge spicules at Sancha (Dayong) or small shelly fossils at Dapu (Cili), or vendotaenids at Shuangxi (Qianyang ) with a great deal of P-bearing nodules, also, in effect, indicate a shallow intertidal-subtidal environment.

The measurement of Corg of extracted bitumen productivity (EBP) and of the ratio of saturated hydrocarbons with aromatic hydrocarbons $(\mathrm{Sa} / \mathrm{Ar})$ from rock samples gathered from a drilling core (ZK101) at Yuanling (Figure 12) shows that the abundance of organic carbon contents appears to correspond to the transgressive part of the sequence. All levels with higher organic matter contents mainly occur in the TSTs of 'Sequence 2, 3 and 5', equivalent to the Member 2 of the Jinjiadong Formation, Member 4 of the Jinjiadong Formation, to the lower parts of the Liuchapo Formation and also to the lowest Xiaoyanxi Formation. The TOC values are, respectively and successively, $4.7 \%, 3.43-3.29 \%$ and $2.62 \%$. The reason for such obviously low organic matter contents $(0.05-0.08 \%$ TOC) within the topmost Liuchapo Formation at the ZK101 drill core section is probably related to the samples collected (chert) or to later tectono-thermal event which also had caused the slumping structures of a rather great scale and the early diagenetic silicification of the black shales. In the Yanwutan section a high organic matter content (up to $13.44 \%$ ) has been obtained from the black carbonaceous shale interbed at the topmost Liuchapo Formation, but the TOC value from a chert-bed collected from the same horizon is quite low $(1.62 \%)$. The TOC value of the black siliceous shales with Ag-V 


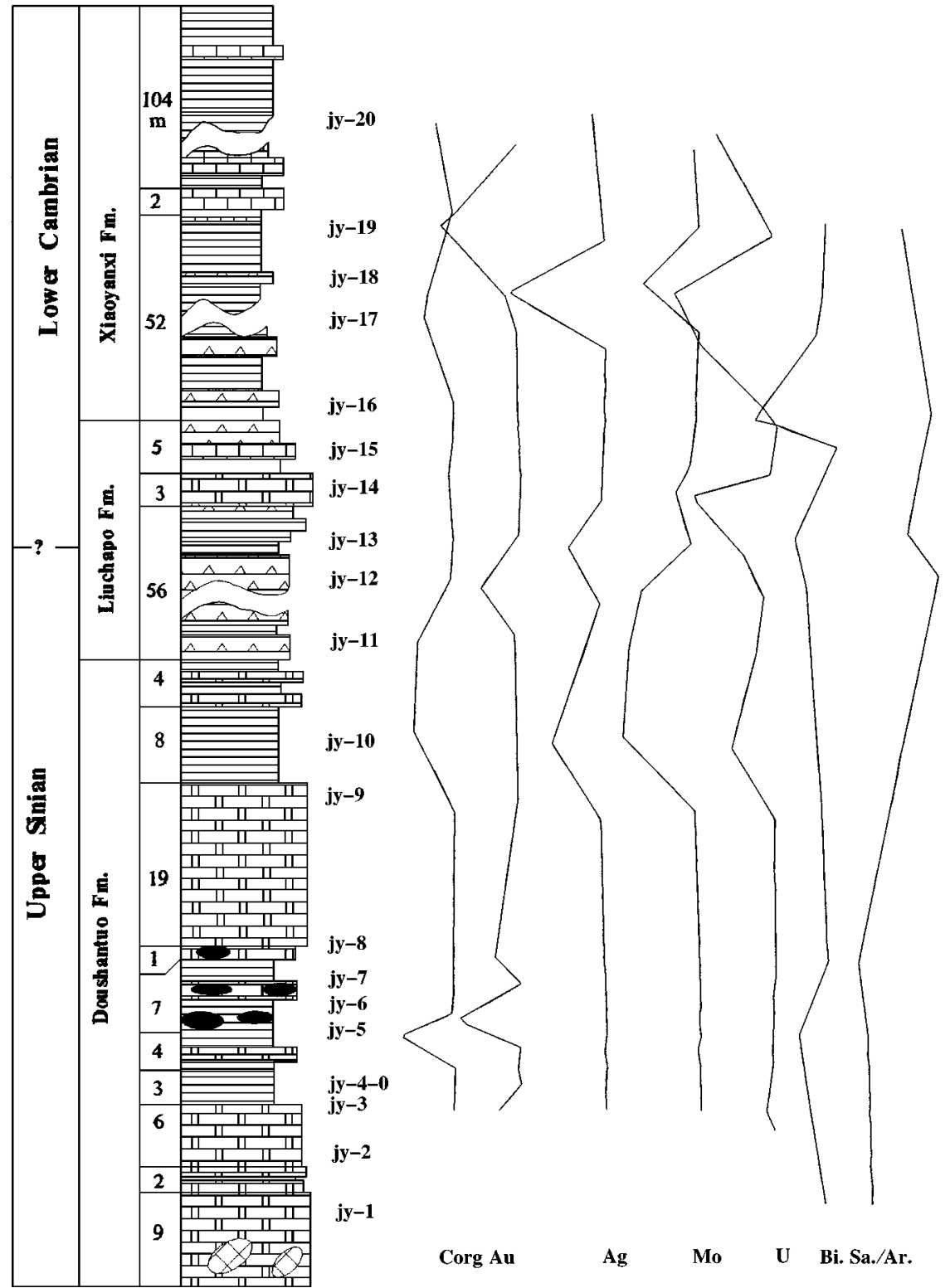

${ }^{o}$ Figure 12 Section of Upper Sinian to Lower Cambrian of the drilling core no. ZK101 at Jianyan in Yuanling County, Hunan, China.

deposits, placed into the Liuchapo Formation (at Qianyang), yielded $4.51 \%$, which is a little higher than that of the ZK101 core-section, but much lower than that of black shales ('algal stone coal') (up to 13-15\% TOC ) at the base of the Xiaoyanxi Formation of Wenshanwan, Ligonggang, Taoyuan County (Steiner, 1994). The result of our investigation indicates that the change of extracted bitumen productivity (EBP) and the ratio of saturated hydrocarbons with aromatic hydrocarbons $(\mathrm{Sa} / \mathrm{Ar})$ in the "black rock series" may reflect the change of sedimentary environment and basically coincides with the sequence turnover. At core section ZK101 the values of EBP and $\mathrm{Sa} / \mathrm{Ar}$ are separately dated at $350 \mathrm{ppm}$ and 0.56 for the topmost Liuchapo Formation, equivalent to 'Sequence 4', which is quite different from those of underlying lower part of the Upper Liuchapo Formation (HST of 'Sequence 3') (EBP: $35 \mathrm{ppm}, \mathrm{Sa} / \mathrm{Ar}$ 1.3) and of the overlying basal Xiaoyanxi Formation (TST of 'Sequence 5') (EBP: $58 \mathrm{ppm}, \mathrm{Sa} / \mathrm{Ar}$ 1.5). This documents the influence of two regressive/transgressive cycles on $\mathrm{EBP}$ and $\mathrm{Sa} / \mathrm{Ar}$. The first cycle occurs between 'Sequence 3' and 'Sequence 4' inside the Upper Liuchapo Formation, which may probably represent the Pre-Cambrian to Cambrian boundary and the second would coincide with the boundary between Liuchapo and Xiaoyanxi Formations (within the basal Cambrian). Whether the change of EBP and $\mathrm{Sa} / \mathrm{Ar}$ could be referred to as indicators for the distinction and identitication of the Precambrian-Cambrian boundary, requires far more evidence and additional support from further detailed studies.

\section{Conclusions}

Integrated litho-, bio- and chemostratigraphic data from the stratigraphic interval of the Nantuo post-glacial to Lower Cambrian "black rock series" in central South China suggest that :

1. Five sequences of third grade could be recognized in the central Yangtze platform and its marginal slope and back-arc basin during this interval. Each sequence turnover is always related to the occurrence of "black rock series" (cherts, shales, dolomites and limestones) accompanied by an oxidizing transgressive system tract following a shallowing upward highstand regressive cycle of the last sequence. Hence, these 5 sets of "black rock series" comprising variable or not fully identical chemical compositions, each beginning with a successive transgression, may provide a valuable tool for the terminal Proterozoic to earliest Cambrian lithological subdivision and interfacies correlation within the investigated region.

2 . These "black rock series" are all formed in a relatively low-energy but current-influenced subtidal environment, regardless of their location in Yangtze intraplatformal depressions or in the Jiangnan platformal marginal basin, or in the Xiang-Qian back-arc basin. These "black rock series" are characterized by high original organic matter contents probably derived from primary rather highly diversified megaalgae, vendobiota, soft-bodied metabiota and prokaryotic bacteria during the Neoproterozoic III, and later from multiphyletic small shelly fossils and planktonic trilobites during the lowest Cambrian. The differentiation of organic matter contents for different black rock types (shales, cherts, dolomites and limestones) of the same horizon is related to paleowheathering activities and to the hydrothermal activities in association with the impregnation of high sulfide-related rare and precious metal elements caused by subsequent tectonothermal events. For major parts of the cherts of the Liuchapo Formation or coeval beds, which are also affected by gravity-induced slump folding the silicification is interpreted to have resulted from prediagenetic hydrothermal replacement of primary black muds.

3. The occurrence of four main biotic assemblages in the terminal Precambrian to earliest Cambrian "black rock series" is related to shallow-water originally oxidizing transgressive environments in the central Yangtze platform and its marginal slope areas. The main reason for the usual absence of most of these organic-walled non-sketetal biota, except for the vendotaenids, may be their preferred warmwater habitats. In the Xiang-Qian back-arc basinal facies the "black rock series" of the same age would probably have been influenced by volcanically derived hydrothermal activities leading to a rising seafloor water temperature during that time, and coincidentally to a relative deep "anoxia" environment as well.

4. The apparent 'anoxia' expressed by these "black rock series" does not mean the absence of oxygen in the original oceanic environment during that time or in the shallow water column, but rather virtually the depletion of oxygen occurs at the sediment/water interface due to sedimentary organic surplus stockpiling (Erdtmann \& 
Wang, 1996 ) and disruption as well as disintegration of organic matter during burial and also during early phases of diagenensis.

5. Two obvious changes in the distribution of REE, EBP and $\mathrm{Sa} / \mathrm{Ar}$ values are observed between 'Sequence 3 and 4' and between 'Sequence 4 and 5' in the back-arc basin facies of Xiang-Qian. The values close to the topmost Liuchapo Formation would be equivalent to those at the Precambrian/Cambrian boundary, marked by the appearance of multiphyletic small shelly fossils in the Yangtze platform, and the latter being coeval with those at the Lihuchapo and Xiaoyanxi boundary, would correspond to the same species which occur between the Yanjiahe and Shuijintuo Formations.

\section{Acknowledgments}

This paper has grown from a joint project, supported by a grant (Er 96-16-1) from the DFG and Chinese Academy of Geological Sciences. The authors is very much indebted to Drs. M. Steiner and E. Wallis from TUB and Prof. Zhang Aiyuan from CUG for their cooperative field work and providing valuable advice on this paper. We especially thank Dr. Luo Xueqian from No. 407 Geological Team in Huaihua, Hunan and Dr. Ye Yushu from No. 403 Geological Team in Shimen, Hunan for guidance and discussions during field work made in Huaihua and Zhangiajie areas, respectively and for their responses to our requests for collecting some core samples.

\section{Rcfcrences}

Brasier,M.D., 1989, China and the Palaeotethyyan belt (India, Pakistan, Iran, Kazakhstan), in J.E. Cowie \& M.D. Brasier eds., The Precambrian-Cambrian Boundary. Oxford and Mongolia Sci. Pub. pp.40-65.

Chen Menge, Chen Yiyuan, Qian Yi, 1981, Some tubular fossils from the Sinian-Lower Cambrian boundary sequence, Yangtze Gorges: Bull. Tianjin Inst. Geol. Min. Res., CAGS, no. 3, pp.117-124 (in Chinese with English abstract).

Chen Menge, Xiao Zhongzeng, 1991, Discovery of the macrofossils in the Upper Sinian Doushantuo Formation at Miaohe, Eastern Yangtze Gorges: Sci. Geol. Sinica, no. 4, pp.317-324 (in Chinese with English abstract).

Chen Ping. 1984. Discovery of Lower Cambrian small shelly fossils from Jijiapo, Yichang, West Hubei and its signficance: Prof. Pap. Stratigr. \& Palaeont. no. 3, pp.49-64 ( in Chinese with Engiish abstract ).

Ding Lianfang, Li Yong, Hu Xiaowu, Xiao Yaping, Su Chunqian, Huang Jiancheng, 1996. Sinian Miaohe Biota: Geol. Pub. House, 1-150 (in Chinese with English summary).

Erdtmann, B-D. \& Wang Xiaofeng, 1996, Sinian black shales: sinks for sedimentary organic surplus stockpiling: 30th IGC. Beijing. Abstracts, v. 2, p. 180

Hunan Bureau of Geology and Mineral Resources, 1988, Regional Geology of Hunan Province: Geol. Mem., MGMR Proc., Ser. 1, No. 8, 1-625, Geol. Pub. House, Beijing (in Chinese with English summary ).

Hubei Bureau of Geology and Mineral Resources. 1990, Regional Geology of Hubei Province: Geol. Mem. MGMR, Proc., Ser. 1, No.9, 1-705, Geol. Pub. House, Beijing (in Chinese with English summary).

Klinkhammer, G., Elderfield, H. and Hudson, A., 1983, Rare earth elements in seawater: Nature, v. 305, no. 15, pp. 185-188.

Ma Guogan, Zhang Zichao, Li Huaqing, 1984, An investigation of the age limits of the Sinian System in South China: Bull. Yichang Inst. Geol. \& Min. Res., CAGS, v. 8, pp. 1-29.
Peng Jun, Xia Wenjie, Yi Haisheng, 1995, Silicon and oxygen isotopic composition and origin analysis of Late Precambrian bedded chert in western Hunan: Geol. Rev. v. 41, no. 19, pp. 34-41 (in Chinese witch Engiish summary).

Steiner, M., 1994, Die Neoproterozoischen Megaalgen Sudchinas.-Berliner geowiss. Abh. 15: 1-146.

Tang Tianfu, Zhang Junmin, and Jiang Xiaojian, 1978, Discovery and significance of the Late Sinian fauna from West Hunan and Hubei: Acta Stratigr. Sinica. v. 2, no. 1, pp. 32-45 (in Chinese with English abstract).

Yi Haisheng, Zeng Yunfu and Xia Wenjie, 1989, Sedmentary facies and origin of bedded siliceous rocks of the Upper Sinian in Hunan, Guizhou and Guangxi region: Minerals and Rocks, v. 9, no. 4, pp. 53-59 (in Chinese with English abstract).

Zhao Ziqiang, Xing Yusheng, Ma Guogan, and Chen Yiyuan, 1985, Biostratigraphy in the eastern Yangtze Gorges area, 1, Sinian: Geol. Pub. House, Beijing, 1-89 (in Chinese with English summary).

Zhao Ziqiang, Xing Yusheng, Ding Qixiu and others, 1988, The Sinian System of Hubei: China Univ. Geol. Press: 1-205 ( in Chinese ).

Wang Xiaofeng is Director and Professor of Yichang Institute of Geology and Mineral Resources, where he has been engaging in the researches of stratigraphy and paleontology since 1965. He has been a Titular Member of the Subcommission on Ordovician Stratigraphy since 1988 and ViceChairman of Paleontological Society of China since 1997. His research interest is mainly Ordovician geology and Ordovician to Lower Devonian graptolite, chitinozoan and zooclast reflectance as well as the origin and evolution of Paleo-Tethys.

Bernd-D. Erdtmann received his PhD (1986) in University of Oslo, Norway is professor at the Institute of Geology and Paleontology, Technical University of Berlin since 1987. He has been a voting member of the Ordovician-Cambrian Boundary Working Group since 1974. His interest is global Ordovician geology, especially the Tremadoc stratigraphy and graptolites. Meanwhile he extended his researches into the PreCambrian bio-, event- and chemostratigraphy and the Neoproterozoic and Lower Paleozoic paleogeographic reconstruction for periGondwana in last several years.
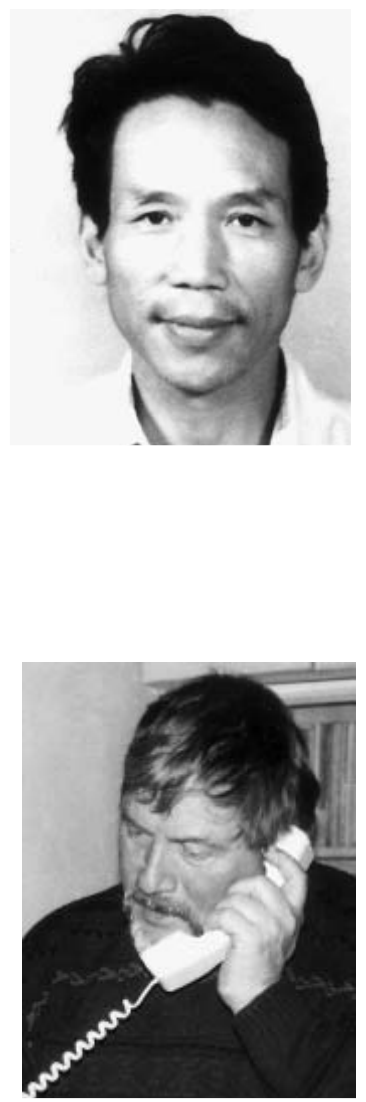